\title{
Mechanical Engineering in Ancient Egypt, Part XXXIX: Statues of Cats, Dogs and Lions
}

Galal Ali Hassaan

\author{
Department of Mechanical Design \& Production, Faculty of Engineering, Cairo University, Giza, Egypt
}

(Emeritus Professor)

\begin{abstract}
The evolution of mechanical engineering in ancient Egypt is investigated in this research paper through studying the production of statues of cats, dogs and lions. Examples from historical eras between Predynastic and Late Periods are presented, analysed and aspects of quality and innovation are outlined in each one. Material, dynasty, main dimension (if known) and present location are also outlined to complete the information about each animal artefact.
\end{abstract}

Keywords: Mechanical engineering, ancient Egypt, cat statues, dog statues, lion statues

\section{INTRODUCTION}

Ancient Egyptians produced statuettes and figurines for some of their animals since the Predynastic Periods. They used a variety of raw materials available in their lands and could produced items ranging from very small size to life size as will be investigated in the present study as indication of the evolution of mechanical engineering in ancient Egypt.

Capart (1905) in his book about primitive art in ancient Egypt presented a number of animal figurines . This included: Palettes in the form of lion, fish, hippopotami and tortoises, mace head in the form of tortoise, vases in the form of animals, furniture feet in the form of bull legs, flint figurines in the form of antelope, goat and sheep, clay and granite figurines of hippopotami, figurines of lions, dogs, baboons and monkeys, cattles, bull head amulets, double bull head amulet and a pottery figurine of a lion [1]. Smith (1960) in his book about ancient Egypt as represented in the Museum of Fine Arts of Boston presented a number of animal figurines including animals in the form of slate palettes, a pottery and faience hippopotamus, ivory inlay from Kerma in the form of animals, wooden panther from the tomb of Pharaohs Thutmose IV and Tutankhamun [2]. Fischer (1968) studied the ancient Egyptian presentation of turtles. He presented a number of turtle statuettes from different historical eras besides a number of objects based in its shape on turtle configuration [3].

Arnold (1995) in his extensive study on Egyptian bestiary presented a large number of animal statues and statuettes of the ancient Egyptians. He presented a gazelle statue from the $18^{\text {th }}$ Dynasty, a three deben weight in the shape of a gazelle from the $18^{\text {th }}$ Dynasty, an antelope head from the $27^{\text {th }}$ Dynasty, an ibex from the $18^{\text {th }}$ Dynasty, head of a jackal from the Late Period, lion from early dynastic, double leopard head from the $12^{\text {th }}$ Dynasty, jerboas from Middle Kingdom, genet ftom the Late Period, turtles from the Old Kingdom, $12^{\text {th }}$ and $26^{\text {th }}$ Dynasties, a dish in the form of bolti fish from the $18^{\text {th }}$ Dynasty, cat from the Late Period, cobra head from $18^{\text {th }}$ Dynasty, cattle from the $12^{\text {th }}$ Dynasty, bull's legs from Early Dunastic, apis bull from Late Period, horse and mouse from $18^{\text {th }}$ Dynasty, hunting and crouching dog from $18^{\text {th }}$ Dynasty, vessel in the form of a monkey and a monkey from the $6^{\text {th }}$ Dynasty. Ambers et. Al. (2008) studied the technical investigation of the Gayer-Anderson cat which was one of the best known objects in the collections of the British Museum Department of Ancient Egypt and Sudan. The cat statue was a life-size cast copper from the Late Period (600 BC). They presented different views for the cat and presented another view for another cat from Louvre Museum with eye inlays.

Stevens (2009) in her article in the UCLA Encyclopaedia of Egyptology presented a number of figurines of animals from the Third Intermediate Period of ancient Egypt. Strandberg (2009) in her $\mathrm{Ph}$. D. Thesis investigated the image and meaning of the gazelle in the ancient Egyptian art. She 

Lions"

presented a gazelle statue from the $18^{\text {th }}$ Dynasty standing on a wooden base representing a desert ground [7]. Lankaster (2012) in his Ph. D. Thesis about Predynastic and Pharaonic era rock art in Egypt's central Eastern desert presented an evidence that ancient Egyptians hunted hippopotamus since the Predynastic Period. He outlined that elephant and giraffe were represented in Naqada I pottery and ibex was found in Predynastic contexts. Dogs were recorded on pottery since Naqada I and II and on palettes and knife handle in Naqada III [8].

Breivik (2013) in her Master of Art Thesis about burial customs in Upper Egypt, Lower Nubia and Sinai desert presented samples of figurines used for this purpose. This included figurine of a clay hippo from Naqada II in the Ashmolean Museum, clay animals figurines from Amrah [9]. Bollen (2015) in her book about excavating the Near East through the tombs, tells and temples presented a number of statuettes of animals: ivory lion's head from the $9^{\text {th }}-7^{\text {th }}$ century BC [10]. Wing (2015) in his Master Thesis in Archaeology on Predynastic Egyptian presentations of animals presented a number of figurines from the Predynastic Period of Egypt. He presented a hippo in the form of a vessel and bead, a clay hippo from Naqada II, canid figurine, bull head amulet from Naqada, hippo comb handle, gazelle knife handle from Naqada II and a hippo amulet from Badari [11].

Wikipedia (2016) wrote an article about hunting, fishing and animals in ancient Egypt. They stated that some animals such as elephants, rhinoceros and hippopotamus lived in different parts of ancient Egypt [12]. Wikipedia (2017) wrote an article about cats in ancient Egypt. They presented a bronze statue of a cat, a lion-headed woman from the Late Period and a seated cat in display in Walters Art Museum [13].

\section{CATS STATUETTES AND STATUES}

According to Hene Springer, cat was demonstrated in Egypt probably around 2000 BC [14] (i.e. during the $11^{\text {th }}$ Dynasty of the Middle Kingdom). We are going to present samples of the appreciation of cats in the ancient Egyptian society through statuettes during historical periods from the $12^{\text {th }}$ Dynasty to the Late Period. The examples may present statuettes for cats or applications in the form of cats such as vessels or amulets.

- The first example is a cosmetic alabaster jar in the shape of a cat from Early $12^{\text {th }}$ Dynasty (1990-1900 BC) in display in the Metropolitan Museum of Art at NY and shown in Figure 1 [15]. The design is really complex since it simulates the whole cat in a setting position with her front legs extended. The height of the cat is $140 \mathrm{~mm}$, the eyes are inlaid with quartz crystal and the whole body is painted

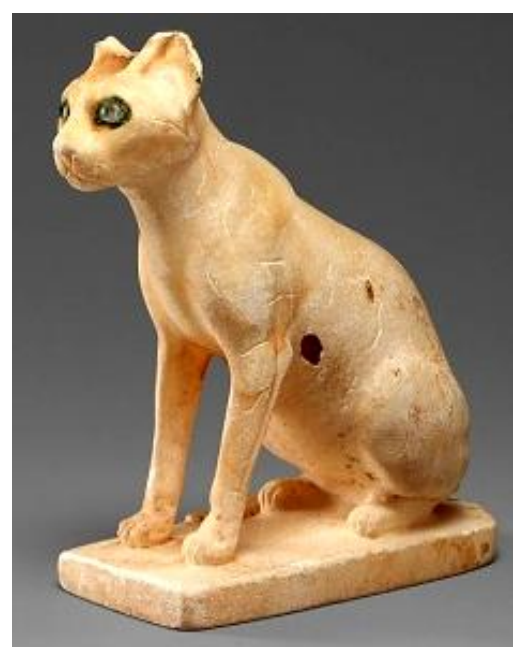

Figure1. Cosmetic jar in the shape of a cat from the $12^{\text {th }}$ Dynasty [15].

- The second example is a faience crouching cat from the 17th Dynasty of the Second Intermediate Period (1500 BC) sold in the Christie's Sale on 26-27 October 2004 at London for 65725 US\$ and shown in Figure 2 [16]. The length of the statuette is $55 \mathrm{~mm}$ and the designer showed the cat setting on her four legs and raising her middle part to take a dome shape. The price paid for this artefact shows how the world if fond of the ancient Egyptian Technology. They paid 1195 US $\$ / \mathrm{mm}$ of the cat length. Definitely it came out from Egypt with few dollars while Egypt is suffering from shortage of dollars. 


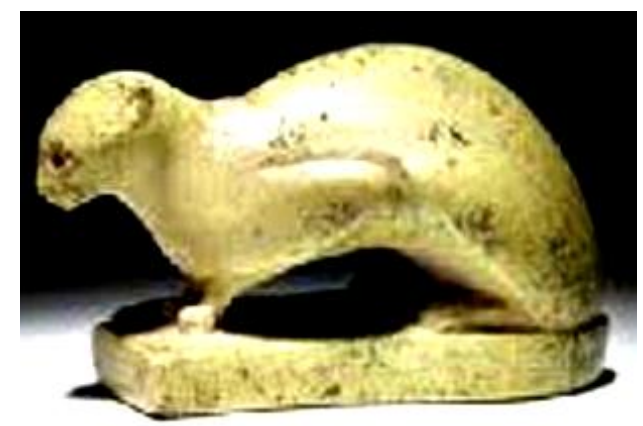

Figure2. Faience crouching cat from the $17^{\text {th }}$ Dynasty [16].

- The third example is a wooden toy cat with bronze teeth and moving jaws from the New Kingdom (1570-1069 BC) in display in British Museum and shown in Figure 3 [17]. The designer showed the cat standing, One of the cat-jaws is movable around a revolute joint and driven by a cord pulled externally as shown in the zoomed image of the head in Fig. 3 through a small hole on the cat head. This is one of the measures of the ancient Egyptian science in the field of applied mechanics.
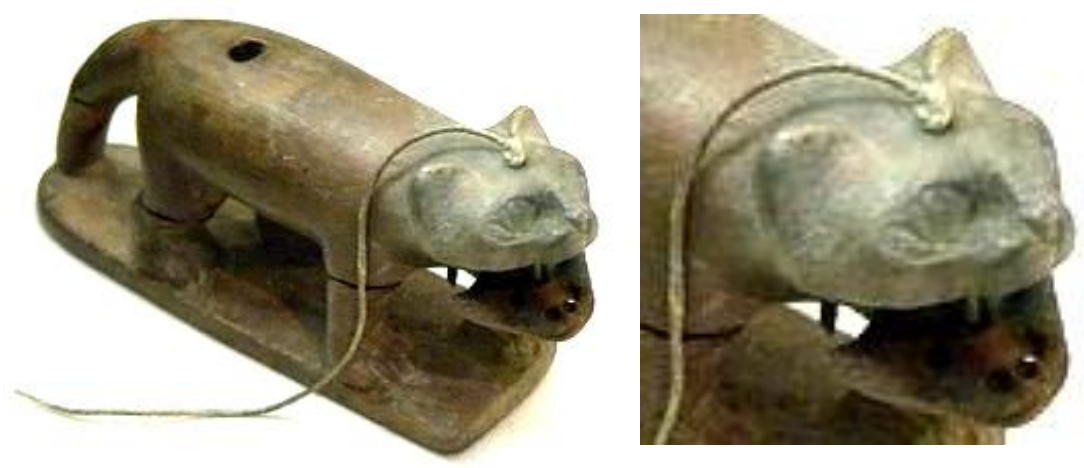

Figure3. Wooden toy cat from the New Kingdom [17].

- The fourth example is a bronze figurine with inlaid gold from the 21st to 26th Dynasties (1081-525 BC) in display in the Los Angles Country Museum of Art shown in Figure 4 [18].
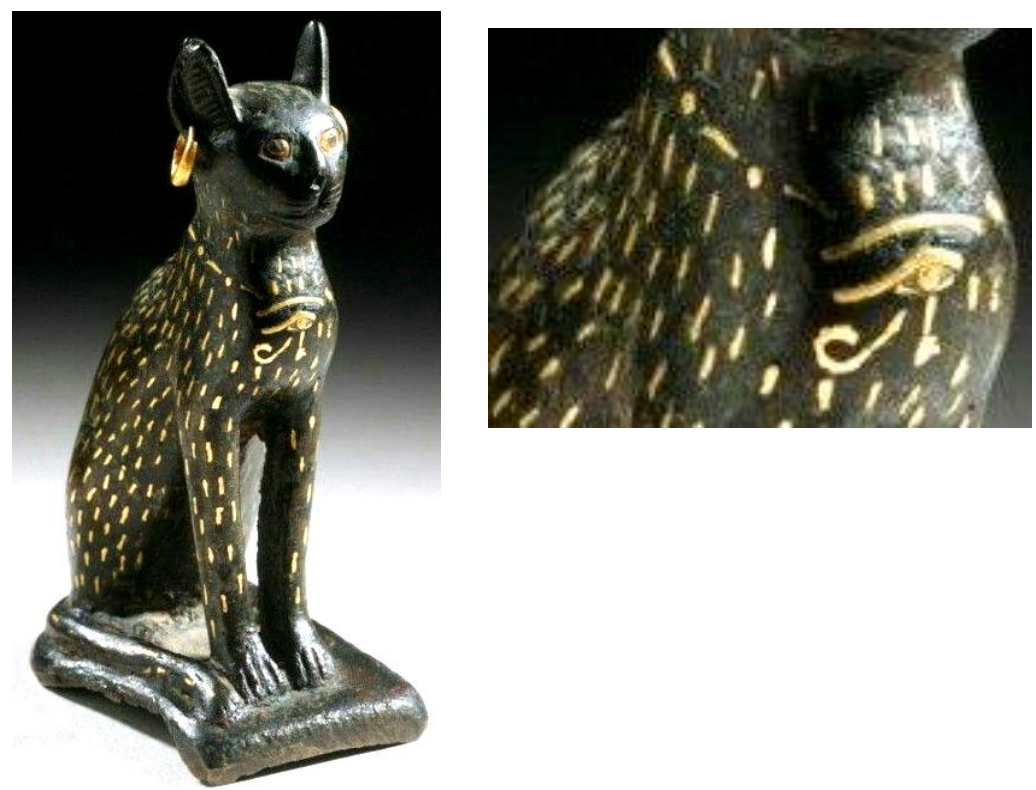

Figure4. Bronze cat figurine from the $21^{\text {st }}-26^{\text {th }}$ Dynasties [18].

- This is an example on the high technology of the ancient Egyptians in the field of metal casting. Even though, the melting point of bronze is $1675 \mathrm{oC}$, they could produce the heat energy required to melt it and the machine elements required to cast it in a very complex 
mould to produce the complex item of Fig.4 integrated with its base. It is decorated by gold traces and a Horus eye symbol on its chest. This inlay requires very high technology level to apply it to sustain time and environmental effects for thousands of years !!.

- The fifth example is a miniature carnelian cat decorating a golden-finger ring from the Third Intermediate Period (1070-1213 BC) in display in the British Museum shown in Figure 5 [17]. Even though carnelian is one of the hardest stones (semi=precious), ancient Egyptians could control its carving process to produce this miniature product with base of the same stone and fixtures with the ring wire through a revolute joint required to produce a swivel finger ring.

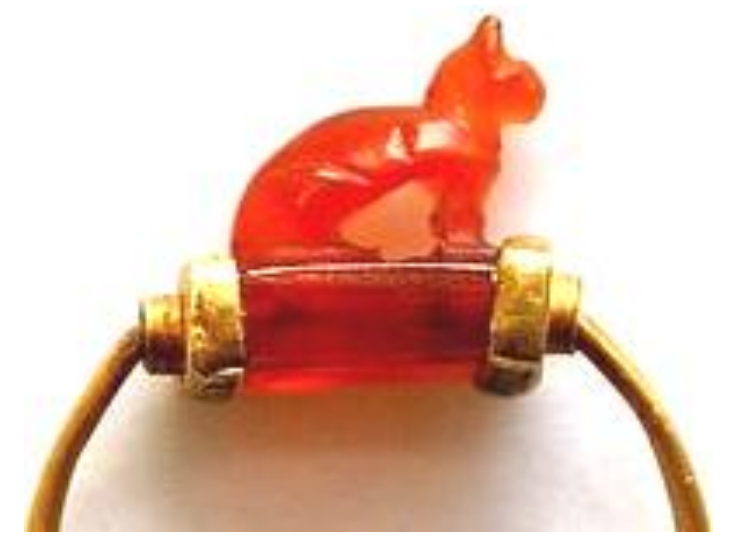

Figure5. Carnelian cat figurine from the $3^{\text {rd }}$ Intermediate Period [17].

- The sixth example is a hollow cast bronze cat statue with gold-leaf eyes from the 22nd Dynasty of the Third Intermediate Period (945-712 BC) in display in the Penn Museum at Birmingham and shown in Figure 6 [19]. The designer showed the cat setting with front hands extending vertically and having a thick moustache and serious look with gold eyes. It is a colossal statue since its height is $0.56 \mathrm{~m}$. The statue reflects the high mechanical technology used in casting this product more than 2730 years ago.

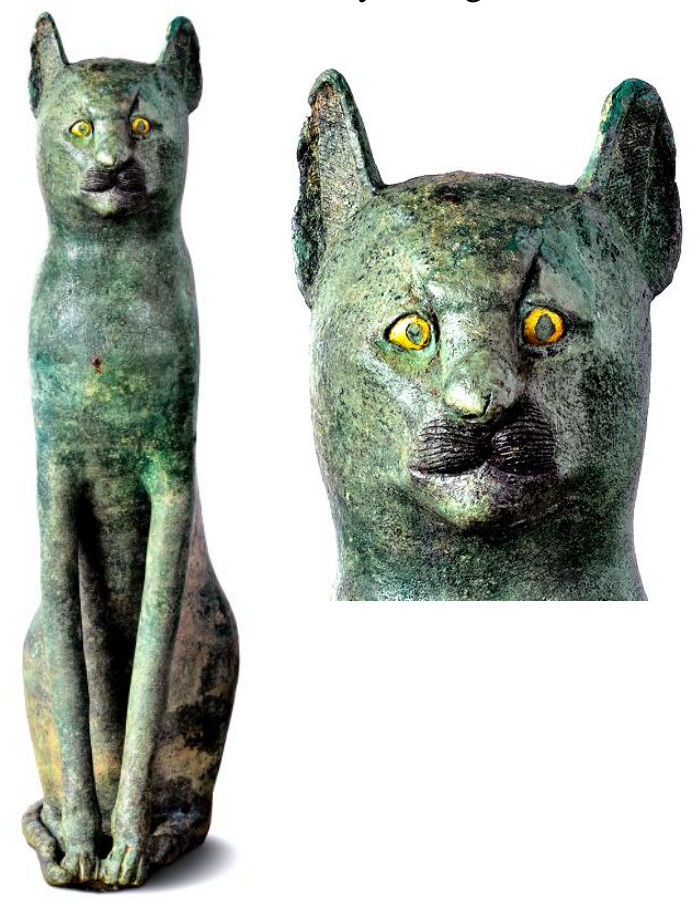

Figure6. Casted bronze cat statue from the $22^{\text {nd }}$ Dynasty [19].

- The seventh example is a $102 \mathrm{~mm}$ hollow cast bronze cat head from the Late Period (664-332 BC) sold in a sale in London on 26th April 2012 for 60270 US\$ (690 US\$/mm) and shown in Figure 7 [20]. Again, this unit was produced using a metal casting process. The details of the cat head complicated the mould design reflecting the high-level of both designers and casting technicians. 
Galal Ali Hassaan "Mechanical Engineering in Ancient Egypt, Part XXXIX: Statues of Cats, Dogs and Lions"

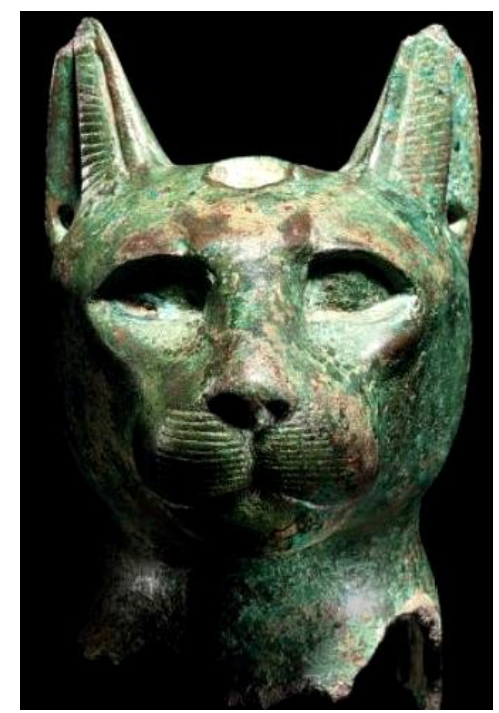

Figure7. Casted bronze cat head from Late Period [20].

- He eighth example is a setting bronze cat from the Late Period (after 600 BC) in display in the British Museum and shown in Figure8 [17]. The designer showed the cat wearing a silver necklace around her neck, gold ring in her nose and scarab on her head. The base under the cat took the shape of a U letter with the hands between the edges of the base. Definitely this and the jewellery will complicate the mould design, but for ancient Egyptians nothing is impossible. It is possible to add the jewellery later after casting and finishing the cat body.
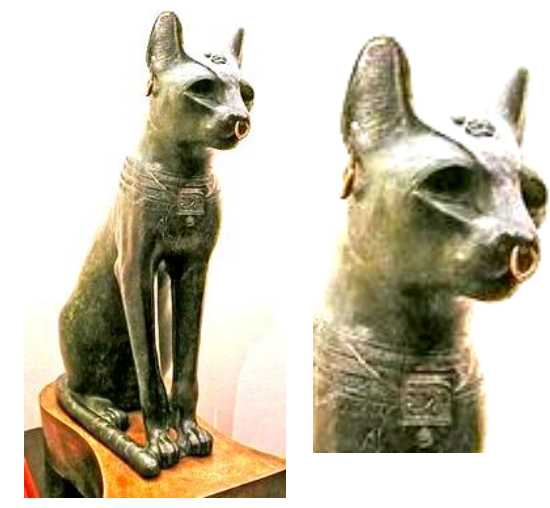

Figure8. Casted bronze cat from Late Period [17].

- The ninth example is a casted bronze model of a setting cat with gold inlay from the 26th Dynasty (600 BC) in display in the Louvre Museum at Paris and shown in Figure 9 [21].

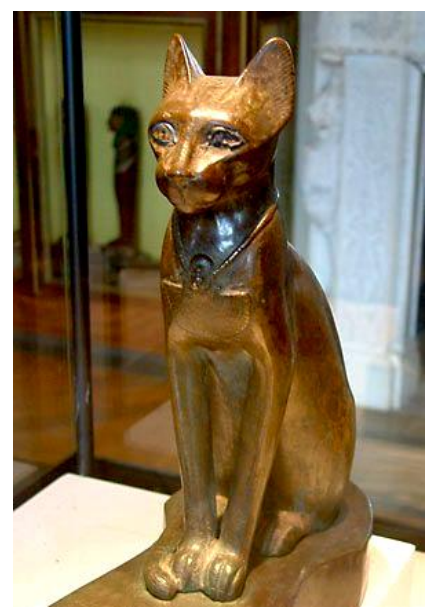

Figure9. Casted bronze cat from the $26^{\text {th }}$ Dynasty [21].

The designer showed the cat wearing a thick blue pectoral and setting her tail besides her right side. 

Lions"

\section{DOGS STATUETTES AND STATUES}

Ancient Egyptians authorized the existence of the dog animal in their societies through statuettes and statues since the Predynastic Period and through the New Kingdom. Here are some examples of their presentation to dogs starting by Naqada I of the Predynastic Period:

- The first example is an ivory dog from Naqada I (4000 BC) in display in the Ashmolean Museum and shown in Figure 10 [22].

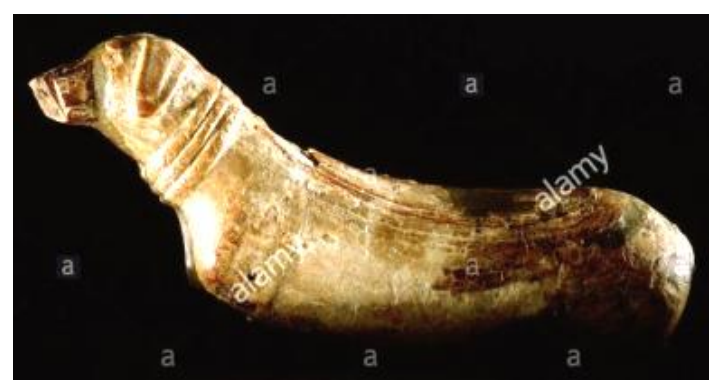

Figure10. Ivory dog from Naqada I [22].

- The second example is again an ivory containers for cosmetics taking the shape of dogs from the Naqada I/Naqada II culture (3900-3300 BC) in display in the Egyptian Museum at Turin and shown in Figure 11 [23]. The design is primitive and the designer tried to show the eyes properly through painting. The location of the container hole is not clear in the view of Figure11.

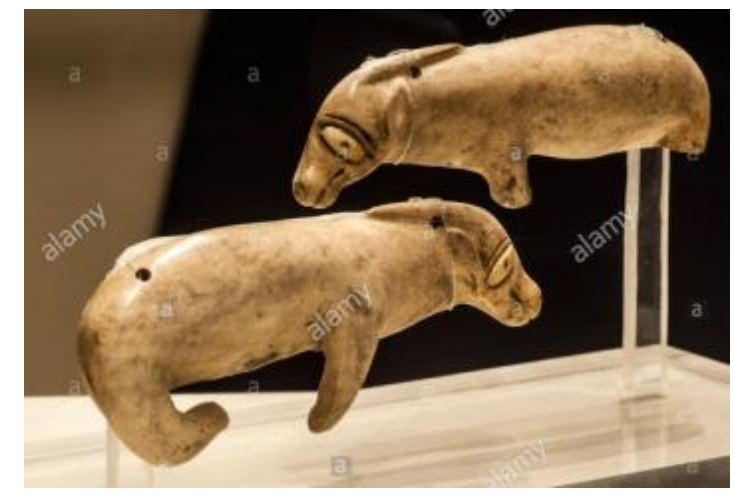

Figure11. Ivory dogs from Naqada I/Naqada II [23].

- The third example is an ivory dog amulet from the 11th Dynasty (2110-2030 BC) in display in the Metropolitan Museum of Art and shown in Figure 12 [24]. Still the design and quality are primitive.

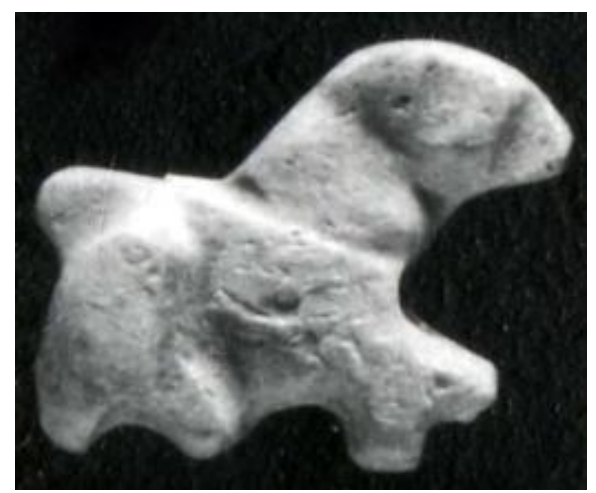

Figure12. Ivory dog from the $11^{\text {th }}$ Dynasty [24].

- The fourth example is a faience figurine of a dog from the 12th Dynasty during the reign of King Senwosret I (1971-1926 BC) in display in the Metropolitan Museum of Art and shown in Figure 13 [25]. The dog length is only $53 \mathrm{~mm}$ and has all its details shown in the figure and produced using the casting process. This is an elaborated design and production compared with the other models presented in figures 10, 11 and 12. 

Lions"

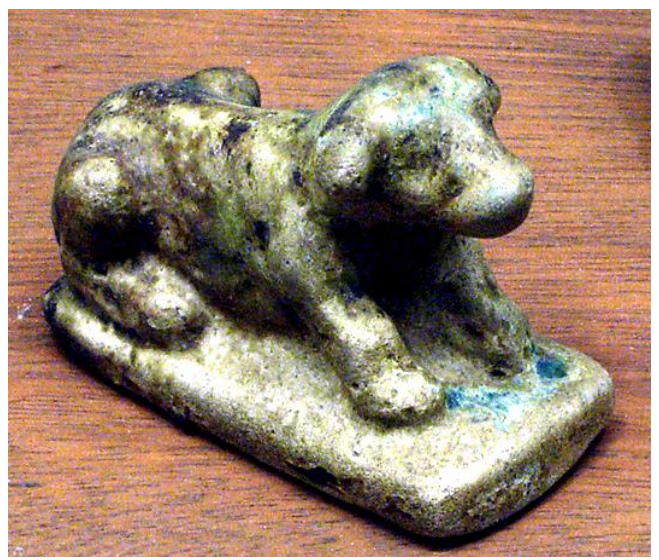

Figure13. Faience dog from the $12^{\text {th }}$ Dynasty [25].

- The fifth example is a cosmetic spoon in the shape of a dog from the 18th Dynasty (1550-1295 BC) in display in the Metropolitan Museum of Art and shown in Fig.14 [26]. The spoon length is $97 \mathrm{~mm}$ and is carved from bone with the dog head acting as a handle. This is a creative design since bone has a medium hardness and is a little brittle making it difficult to carve and produce a complex shape like that in Figure 14 and produce the details of the dog face and legs. Even though the designer showed the dog putting his right front $\log$ on his left front one and his chin over his left front leg.

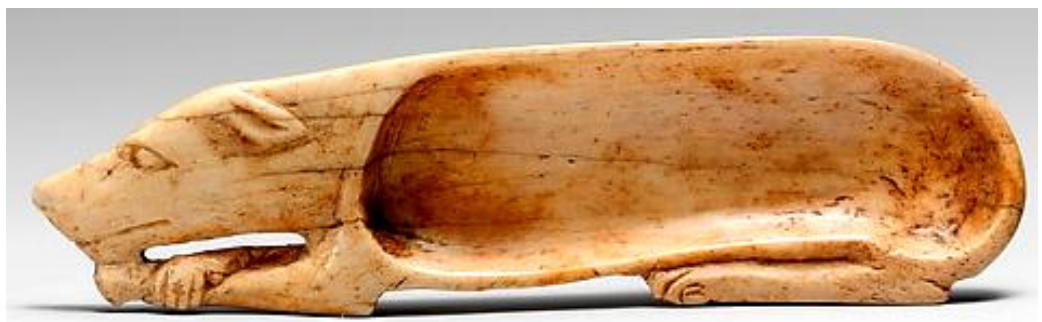

Figure14. Bone dog spoon from the $18^{\text {th }}$ Dynasty [26].

- The sixth example is an ivory mechanical hunting dog from the 18th Dynasty, reign of the Pharaoh Amenhotep III (1390-1353 BC) in display in the Metropolitan Museum of Art and shown in Figure 15. The dog length is $180 \mathrm{~mm}$ and opens and closes his mouth using a lever under his chest. This is an outstanding example of the elaborated level of the carving process during the 18th Dynasty and the role of mechanical engineering in supporting the design of such dynamic products. The designer used revolute joints and a lever in designing this dog.

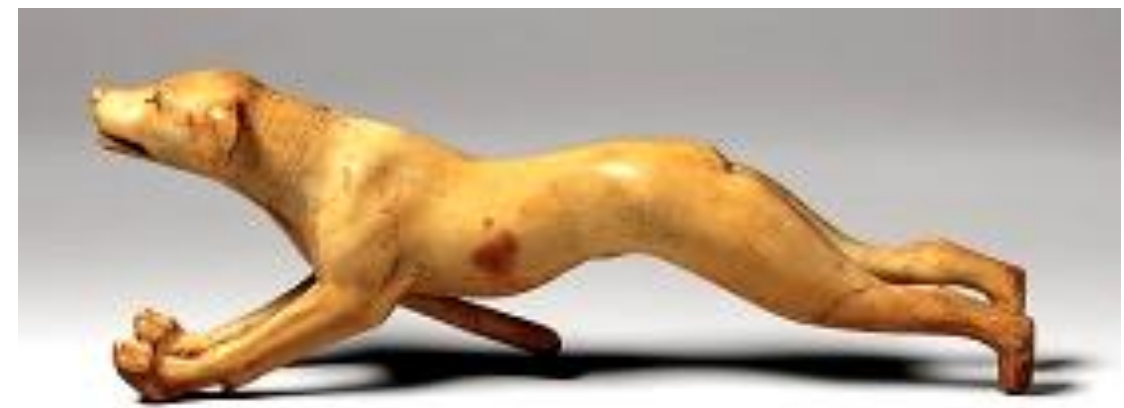

Figure15. Ivory hunting dog from the $18^{\text {th }}$ Dynasty [27].

- The seventh example is bronze figurine of a dog with an ivory fish in its mouth from Late 18th Dynasty (1350 BC) in display in the British Museum and shown in Figure 16 [28]. It is not clear what is on the rear back of the dog. The dog and the base are integrated with each other and the mould designer has to consider this which complicated the design which is already complex because of the details of the dog face, front legs, back legs and what is on his back, besides he has to make the mouse open a little bit to attach the ivory fish later. 
Galal Ali Hassaan "Mechanical Engineering in Ancient Egypt, Part XXXIX: Statues of Cats, Dogs and Lions"

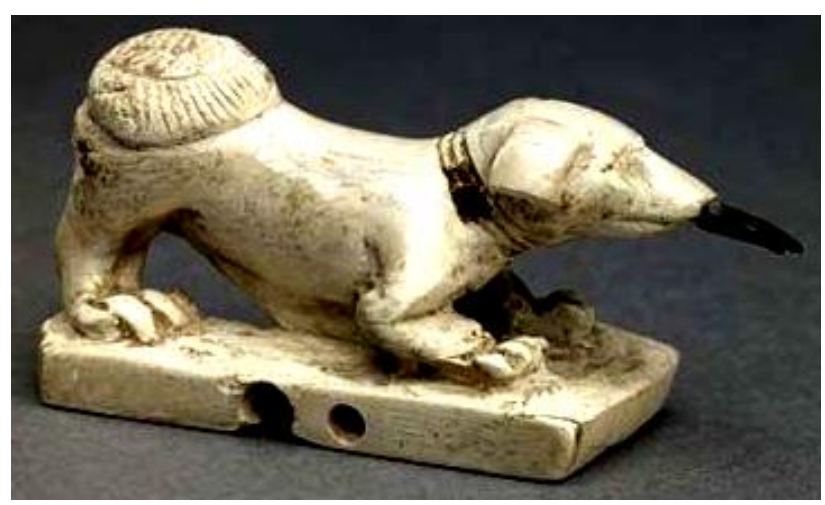

Figure16. Bronze dog from Late $18^{\text {th }}$ Dynasty [28].

\section{LIONS STATUES}

Lions are wild animals characterized by ultimate strength. Therefore, even though they don't live in Egypt, ancient Egyptians appreciated their strength and translated this appreciation to statues starting from the Predynastic Period and up to the $30^{\text {th }}$ Dynasty. Here, we present some of the lion examples over the different historical eras of ancient Egypt:

- The first example is a pottery lion from Naqada III (3200-3000 BC) in display in the Ashmolean Museum at Oxford and shown in Figure 17 [29]. The ancient Egyptian could produce this good artefact using the River Nile mud from more than 5000 years and it is still shining and the line face elements indicating the strength of the lion.

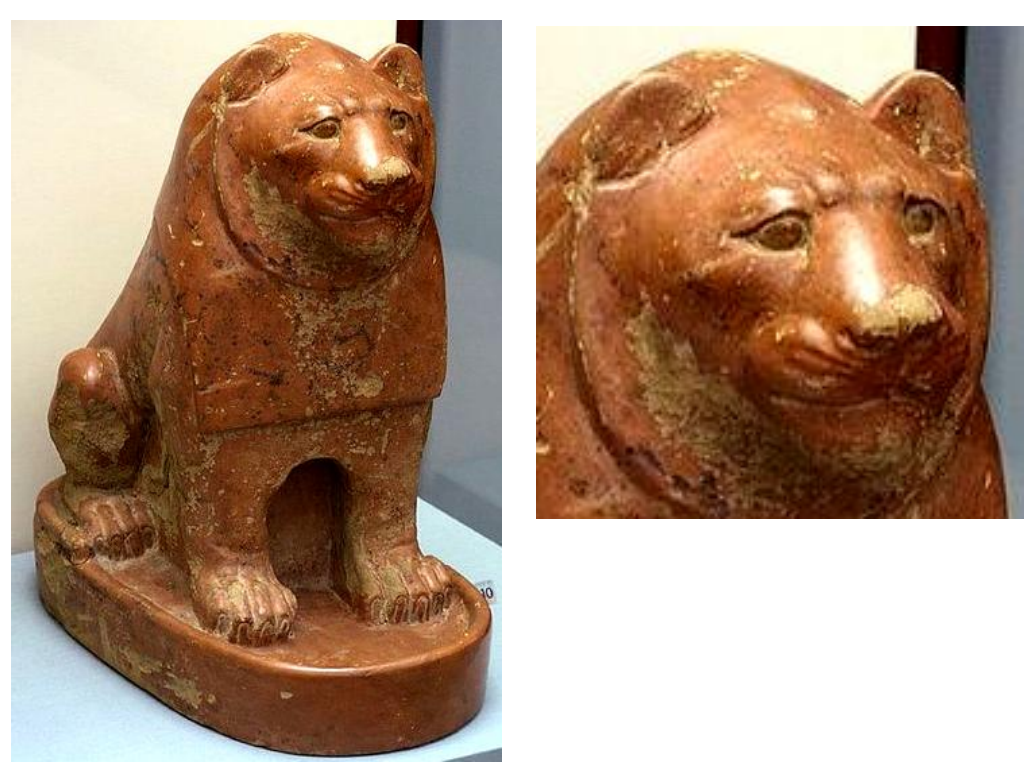

Figure17. Pottery lion from Naqada III [29].

- The second example is a $120 \mathrm{~mm}$ height quartz lion from the Early Dynastic Period (1st and 2nd Dynasties) (3000-2700 BC) in display in the Metropolitan Museum of Art and shown in Figure 18 [30]. The work is primitive and not attractive. However, it shows the lion relaxing with right front leg on left front leg and its chin on its right front leg. The carver could produce smooth surfaces of the lion even though quarts is one of the hardest stones.

- The third example is a $2.01 \mathrm{~m}$ length granite lion from the Old Kingdom, 4th-5th Dynasties (2575-2450 BC) in display in the Metropolitan Museum of Art and shown in Figure 19 [31]. The quality of the product is much better than that of the lion of the Early Dynastic Period. This is simply because the carvers of this period have great proficiency in carving hard stones such as granite which was clear in carving human statues [32]. The details of the lion face and his body are much better than that in Figure 18. 
Galal Ali Hassaan "Mechanical Engineering in Ancient Egypt, Part XXXIX: Statues of Cats, Dogs and Lions"

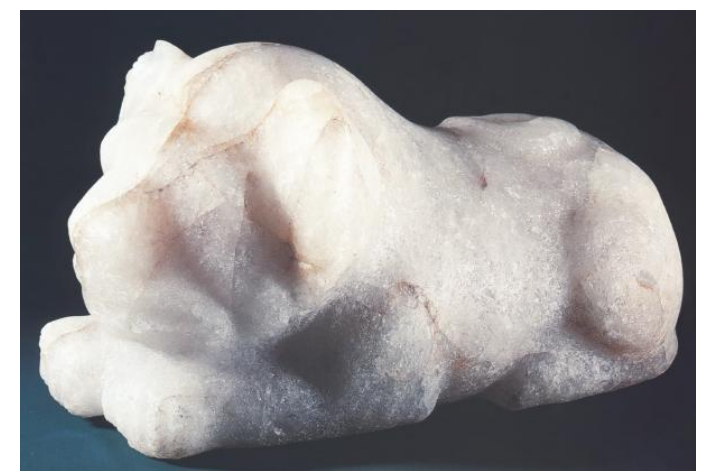

Figure18. Quartz lion from the Early Dynastic [30].

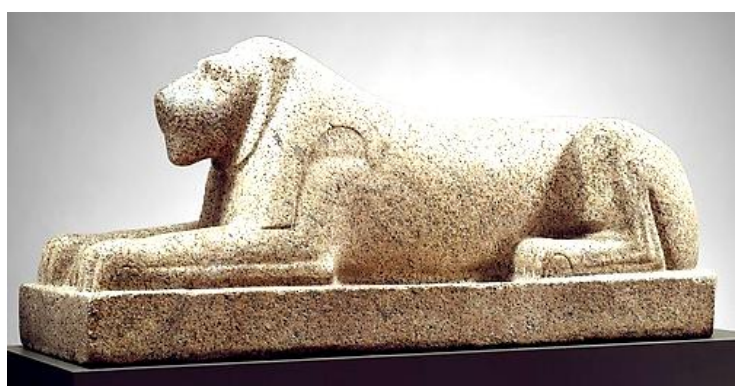

Figure19. Granite lion from the $4^{\text {th }}-5^{\text {th }}$ Dynastic [31].

- The fourth example is a terracotta statue of a seated lion from the 6th Dynasty of the Old Kingdom (2250 BC) in display in the Ashmolean Museum at Oxford and shown in Figure 20 [33]. The design of this lion statue is similar to that of Naqada III (Figure 17) but with better finishing producing shining surfaces.

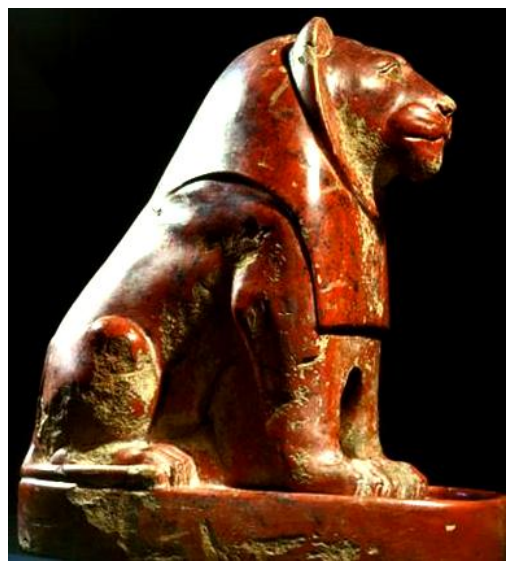

Figure20. Setting lion from the $6^{\text {th }}$ Dynastic [33].

- The fifth example is a diorite head of a line female from the 18th Dynasty of the New Kingdom during the reign of Pharaoh Amenhotep III (1388-1350 BC) sold in a sale in NY on 12th December 2013 for 4197000 US\$ !! and shown in Figure 21 [34]. The head length is 355 $\mathrm{mm}$ and the details of the face are carved professionally with very smooth surfaces.

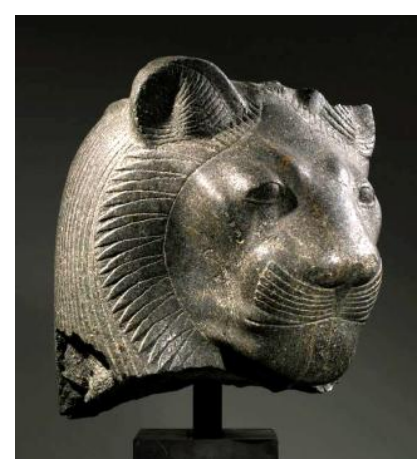

Figure21. Diorite lion head from the $18^{\text {th }}$ Dynasty [34]. 

Lions"

- The sixth example is a 2.16 m length granite lion statue of Pharaoh Amenhotep III of the 18th Dynasty in display in the British Museum and shown in Figure 22 [35]. The top technology in all production engineering aspects is achieved in this wealthy dynasty, Dynasty 18. Using the hard granite stone, the carver could produce this wonderful piece reflecting the actual horrible pose of the lion as shown in the zoomed image of the lion's head in Figure 22.
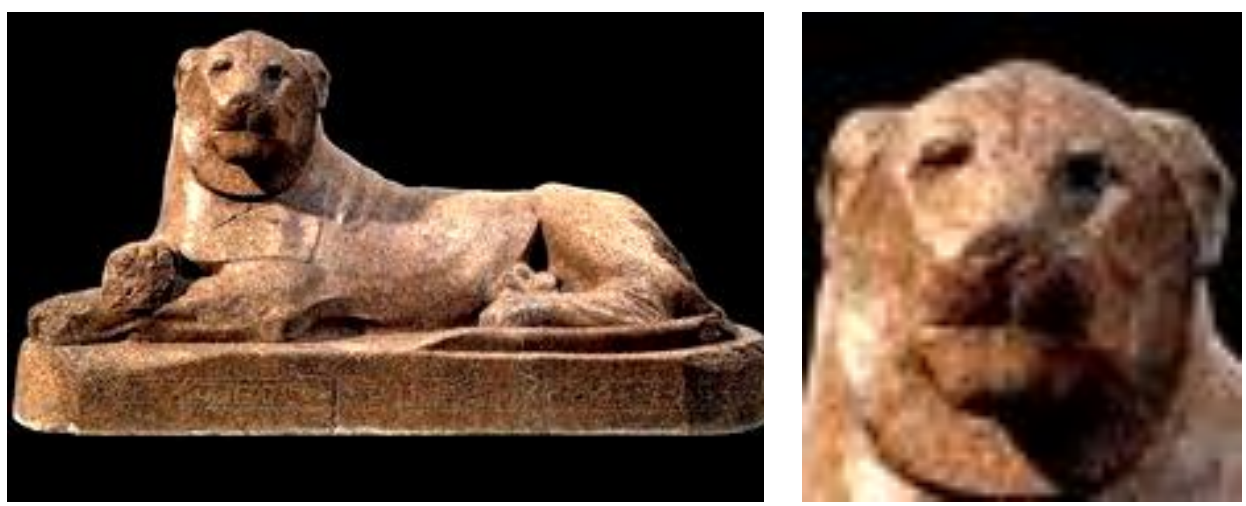

Figure22. Granite lion from the $18^{\text {th }}$ Dynasty [35].

- The seventh example is a granite lion statue of Nectanebo I, the first Pharaoh of the 30th Dynasty of the Late Period (380-362 BC) in display in the Vatican Museum at Rome and shown in Figure 23 [36]. This is again a wonderful design and carving using granite, one of the hardest stones and producing very difficult position for the lion putting its left front leg on the right one and his tail on the vertical side of the granite base which is inscribed by the Cartouche of the Pharaoh.

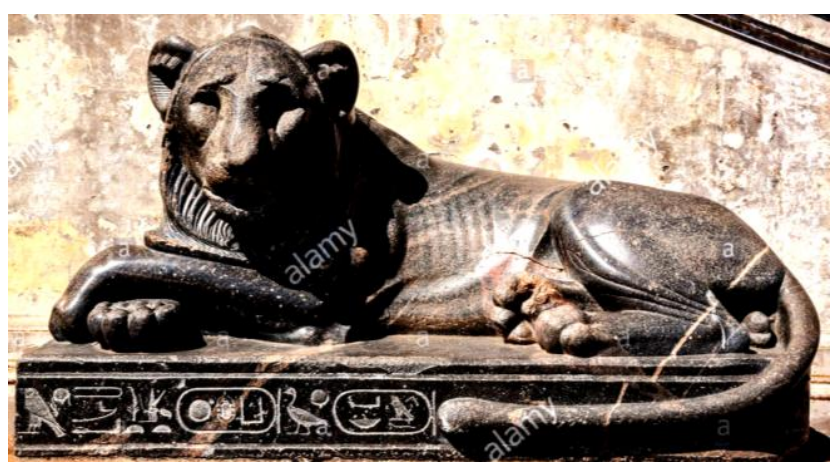

Figure23. Granite lion from the $30^{\text {th }}$ Dynasty [36].

- The eighth and last example of line statues from ancient Egypt is a wooden furniture leg taking the shape of a lion from the Late Period (664-332BC) in display in the Metropolitan Museum of Art and shown in Figure 24 [37]. The lion is shown setting on a Lotus flower looking straight in its eyes level. Its pose is clarified in the zoomed image of its face and what is amazing is its age. It is more than 2350 years and still withstanding the deterioration factors associated with wood products.
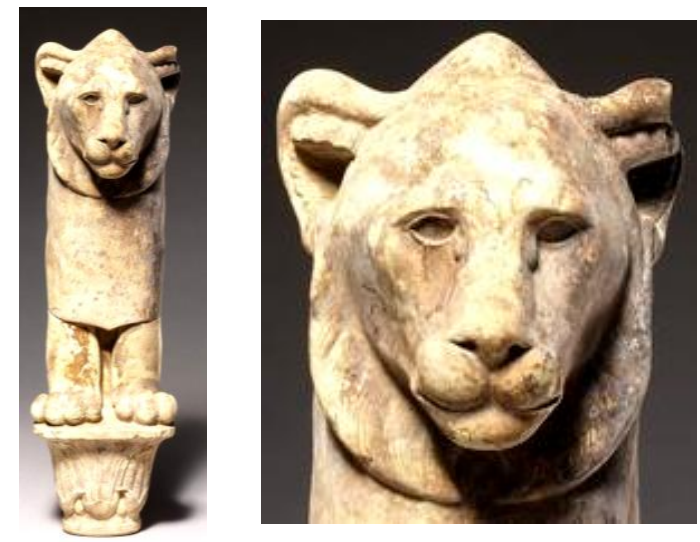

Figure24. Wooden lion as a furniture leg from the Late Period [36]. 
Galal Ali Hassaan "Mechanical Engineering in Ancient Egypt, Part XXXIX: Statues of Cats, Dogs and Lions"

\section{CONCLUSION}

- The evolution of mechanical engineering during the ancient Egypt history was investigated in this research paper through the production of cats, dogs and lions statues.

- The ancient Egyptians produced cat statues and applications documented from the $12^{\text {th }}$ Dynasty of the Middle Kingdom.

- They produced an alabaster jar in the shape of a cat during the $12^{\text {th }}$ Dynasty.

- They used different materials for cat statues production including: alabaster (during the $12^{\text {th }}$ Dynasty), faience and wood (during the $17^{\text {th }}$ Dynasty), bronze (during the $21 \mathrm{t}$ to $30^{\text {th }}$ Dynasties) and carnelian (during the Third Intermediate Period).

- They produced dog statues starting from the time of Naqada I of the Predynastic Period.

- Materials used in dog statues production were: ivory (during Naqada I, Naqada II, $11^{\text {th }}$ Dynasty and $18^{\text {th }}$ Dynasty), bone (during the $18^{\text {th }}$ Dynasty) and bronze (during the $18^{\text {th }}$ Dynasty).

- They produced a mechanical hunting dog statue during the $18^{\text {th }}$ Dynasty capable of opening and closing his mouth using an external lever.

- They invented a cosmetic spoon in the shape of a dog using bone during the $18^{\text {th }}$ Dynasty.

- They started producing lion statues during Naqada III of the Predynastic Period.

- Materials used in producing lion statues were: pottery (during Naqada III), quartz (during Early Dynastic Period), granite (during the Old Kingdom, $18^{\text {th }}$ Dynasty and $30^{\text {th }}$ Dynasty), diorite (during the $18^{\text {th }}$ Dynasty), terracotta (during the $6^{\text {th }}$ Dynasty) and wood (during the Late Period).

- They produced granite lion statues in the $18^{\text {th }}$ Dynasty having more than two meters length.

- Wonderful lion stone statues were produced during the $18^{\text {th }}$ and $30^{\text {th }}$ Dynasties.

- One of the applications of lion statues was furniture legs during the Late Period.

\section{REFERENCES}

[1] J. Capart, "Primitive art in Egypt", H. Grevel \& Co., London, 1905.

[2] W. Smith, "Ancient Egypt as represented in the Museum of Fine Arts, Boston", Museum of Fine Arts, Boston, 1960.

[3] H. Fisher, Ancient Egyptian Presentations of turtles", The Metropolitan Museum of Art Papers, Paper 13, The Metropolitan Museum of Art, 1968.

[4] D. Arnold, "An Egyptian Bestiary", The Metropolitan Museum of Art Bulletin, pp.7-64, Spring 1995.

[5] J. Ambers, et. al., "A new look at an old cat: a technical investigation of the Gayer-Anderson cat", The British Museum Technical Research Bulletin, vol.2, issue 1, pp.1-12, 2008.

[6] A. Stevens, "Domestic religious practices", UCLA Encyclopedia of Egyptology, 1010, version 1, December 2009.

[7] A. Strandberg, "The gazelle in ancient Egypt art:image and meaning", Ph. D. Thesis, Uppsala University, October 2009.

[8] F. Lankester, "Predynastic and Pharaonic era rock art in egypt's Central Eastern desert: Distribution, dating and interpretation", Ph. D. Thesis in Archaeology, Durham University, 2012.

[9] K. Breivik, "Comparative analysis of early bronze age burials", M. A. Thesis in Archaeology, Bergen University, May 2013.

[10] E. Bollen, "Tombs, tells and temples: excavating the Near East", Sydney University Museums, 2015.

[11] G. Wing, "Predynastic Egyptian representations of animals: The journey from nature to art and beyond", Master of Archaeology, University of Durham, 2015. 
Galal Ali Hassaan "Mechanical Engineering in Ancient Egypt, Part XXXIX: Statues of Cats, Dogs and Lions"

[12] Wikipedia, "Hunting, fishing and animals in ancient Egypt", http://en.wikipedia.org/wiki/ Hunting_fishing_and_animals_in_ancient_egypt , 2016.

[13] Wikipedia, "Cats in ancient Egypt", http://en.wikipedia.org/wiki/Cats_in_ancient_egypt., 2017.

[14] H. Springer, "The cat in ancient Egypt, Tour Egypt", http://www.touregypt.net/egypt-info/ magazine-mag04012001-magf1.htm, 2017.

[15] Metropolitan Museum, "Cosmetic jar in the shape of a cat", http://www.metmuseum.org/art/ collection/search/544039?utm_source=pinterest\&utm_medium=social\&utm_campaign=cats , 2017.

[16] Christies, "An Egyptian green faience figure of a crouching cat", http://www.christies.com/ lotfinder/lot/an-egyptian-green-faience-figure-of-a-4364399-details.aspx?intObjectID=4364399 , 2017.

[17] Little House Cats, "British Museum cats", http://www.littlehouseofcats.com/cats-in-art/museumcats/british-museum-cats/ , 2011.

[18] L. Bennet, "Figurine of Bastet as a cat", https://www.pinterest.com/pin/525795325230060794/

[19] Pen Museum, "Hollow cast bronze statue of a seated cat", https://www.penn.museum/ collections/object/267502, 2017.

[20] Stone Finder, "An Egyptian bronze cat head, Late Period", https://www.pinterest.com/pin/ $137641332334597692 /$

[21] J. Jasminka, "An ancient Egyptian figurine of a cat", https://www.pinterest.com/pin/ $8233211792698400 /$

[22] Alamy, "Ivory carving of a dog, ancient Egyptian", http://www.alamy.com/stock-photo-ivorycarving-of-a-dog-ancient-egyptian-predynastic-period-c4000-bc-28349197.html

[23] Alamy, "Containers for cosmetics in ivory, Predynastic Period" , http://www.alamy.com/stockphoto-italy-piedmont-turin-egyptian-museum-new-staging-containers-for-cosmetics80522880.html

[24] Metropolitan Museum, "Dog amulet", http://www.metmuseum.org/art/collection/search/5458 56?rpp $=30 \& \mathrm{pg}=2 \& \mathrm{rndkey}=20160111 \& \mathrm{ao}=\mathrm{on} \& \mathrm{ft}=* \&$ where $=$ Africa $\& \mathrm{pos}=52$

[25] Metropolitan Museum, "Figurine of a dog", http://www.metmuseum.org/art/collection/search/ 555715\#!\#fullscreen, 2017.

[26] Metropolitan Museum, "Cosmetic dish in the shape of a dog", http://www.metmuseum.org/art/ collection/search/545210?utm_source=pinterest\&utm_medium=social\&utm_campaign=dogs , 2017.

[27] Metropolitan Museum of Art, "Mechanical dog", http://www.metmuseum.org/art/ collection/ search/544519?img=3, 2017.

[28] P. Bystricky, "Figure of a dog with fish in mouth", https://www.pinterest.com/pin/43888992 6167615969/

[29] J. Bodsworth, "Egyptian pottery lion", https://commons.wikimedia.org/wiki/File:Ancient_ Egyptian_pottery_lion.JPG, 2007.Arnold, 1995, p.17.

[30] Metropolitan Museum, "Recumbent lion", http://www.metmuseum.org/art/collection/search/ 549541

[31] G. A. Hassaan, "Mechanical engineering in ancient Egypt, Part XXXIII: Stone statues industry (Predynastic to Old Kingdom)", International Journal of Recent Engineering Science, vol.30, pp.5-16, December 2016.

[32] M. Fernandez, "Statue of a seated lion from Old Kingdom", https://www.pinterest.com/pin/ 354799276872013639/

[33] Sothebys, "An Egyptian diorite head of goddess Sekhmet, $18^{\text {th }}$ Dynasty", http://www.sothebys. com/en/auctions/ecatalogue/2013/antiquities-n09056/lot.9.html , 2017.

[34] British Museum, "The Prudhoe lions", http://www.britishmuseum.org/research/collection_ online/collection_object_details.aspx?objectId=117626\&partId $=1$ 
Galal Ali Hassaan "Mechanical Engineering in Ancient Egypt, Part XXXIX: Statues of Cats, Dogs and Lions"

[35] Alamy, "One of two granite recumbent lions made for Pharaoh Nectanebo I", http://www.alamy.com/stock-photo-one-of-two-granite-recumbent-lion-statues-made-for-thepharaoh-nectanebo-50699637.html

[36] D. Taylor, "Lion furniture leg, Late Period", https://www.pinterest.com/pin/42066442141 $6546097 /$

\section{AUTHOR'S BIOGRAPHY}

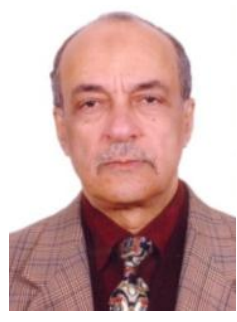

\section{Galal Ali Hassaan,}

- Emeritus Professor of System Dynamics and Automatic Control.

- Has got his B.Sc. and M.Sc. from Cairo University in 1970 and 1974.

- Has got his Ph.D. in 1979 from Bradford University, UK under the supervision of Late Prof. John Parnaby.

- Now with the Faculty of Engineering, Cairo University, EGYPT.

- Research on Automatic Control, Mechanical Vibrations, Mechanism Synthesis and History of Mechanical Engineering.

- Published more than 190 research papers in international journals and conferences.

- Author of books on Experimental Systems Control, Experimental Vibrations and Evolution of Mechanical Engineering.

- Chief Justice of the International Journal of Computer Techniques.

- Member of the Editorial Board of some international journals including IJEERT.

- Reviewer in some international journals.

- Scholars interested in the authors publications can visit: 